\title{
Agogo Presbyterian College of Education Under the Missionaries and After Take-Over by the Government (1931-2013): A Comparative Study
}

\author{
*Frederick Mensah Bonsu, Augustine Adjei, David Doe Ayornoo \\ MPhil/Med. Wesley College of Education, Kumasi- Ashanti. Ghana West-Africa \\ Mphil/Med. Offinso College of Education, Offinso Ashanti. Ghana West Africa \\ MA. Ada College of Education. Ada-Eastern. Ghana West Africa
}

\begin{abstract}
The study analyzed the Agogo Presbyterian College of Education (1930-1971) and when it was taken over by the Government (1972-2013). This became relevant in the wake of the recent plea by the churches that the Government should hand over Mission Schools to the churches. The study therefore examines the state of management and leadership and infrastructural development both under the regime of the Missionaries and the Government. It also sought to assess academic standard of the students, and the discipline of the College, qualification of the teachers, supervision, and students' patronage of library and entry grade of students to the College with the view of establishing the progression or retrogression over the period. In doing this, a comparative study was undertaken and data were derived from archival materials of the Agogo Presbyterian College of Education, and direct interviews with past Principals and Administrators of the College. The results revealed that despite an increase in student-intake (210 students in 1942 to 750 students in 2014) with a corresponding increase of teachers (from 5 missionary teachers with lower academic degrees in 1931 to 28 teachers with masters qualifications), inadequate infrastructural development; lack of discipline and competitions among students have characterized APCE since it was managed by the Government as compared to the Missionaries. The study recommends that the Government would complete the construction of the studentse hall complex, and also put up large auditorium and classroom blocks to accommodate the high students' intake in the College to enhance education delivery.
\end{abstract}

Keywords: APCE - Agogo Presbyterian College of Education, BECE - Basic Education Certification Examination ,CRDD - Curriculum Research and Development Division , CMC - Church Missionary Society , CCG - Christian Council of Ghana , DBE - Diploma in Basic Education ,GIMPA - Ghana Institute of Management and Public Administration, GET FUND - Ghana Education Trust Fund , GES Ghana Education Service , GTZ - Ghana Japan Cooperation , GCE - General Certificate Examination , HIV/AIDS - Human Immune Virus/ Acquired Immuno Deficiency Syndrome , ICT - Information Communication and Technology ,JHS - Junior High School, KVIP - Kumasi Ventilated Improved Pit , KJV - King James Version , MP - Member of Parliament, MoE - Ministry of Education , NTCE National Council of Tertiary Education , NDC - National Democratic Congress ,PCG- Presbyterian Church of Ghana and PDE - District Director of Education

\section{Background to the Study}

At the 1928 synod of the Presbyterian Church of the Gold Coast, the Basel Mission was requested to establish Girlse Boarding School and Teacher Training College in the Ashanti Region. Consequently, the two institutions were founded in 1931 by a young missionary teacher called Miss Helena Schlatter (later Mrs. Haegele). The Girls ${ }^{\text {ee }}$ School was to feed the Teacher Training College with its successful students. Therefore the Girls Boarding School should never be left out whenever talking about the Agogo 
Presbyterian College of Education. One can agree with Bartels (1965), that the missionary bodies came to Africa and established schools to help in the propagation of their doctrine. The aim of establishing the Womenes Training College was to train Ghanaian women teachers for the Girlse Middle School which had just started and to inculcate in these young teachers, Christian principles that would help them to be good teachers, parents and leaders. Another aim of the College was to prepare the teachers to build Christian homes and take up leadership role in the society. The Girlse School was used as a demonstration school by the students in the College.

During World War II, the College was evacuated to Akropong when the Army took over the buildings for use as a training centre. In 1943 saw the "exiles", that is the students, back at Agogo to continue their academic work. Between 1945 and 1947, there was a marked physical expansion of the College to meet the over growing student population and in 1947 the College was officially inaugurated. At a solemn ceremony in 1950 the Basel Mission Training College was absorbed by the Presbyterian Church and renamed the Agogo Presbyterian Women 'e s Training College. In 1972, the last Basel Mission Principal, Miss Debrunner handed over the headship of the College to a Ghanaian, Miss Vida Anno-Kwakye. From that time, the government of Ghana took over the full responsibility in the management of the school.

\section{Statement of the Problem}

The issue of whether the schools built and run by missionaries and taken over by the government should be returned to the Churches that used to run them or not has been discussed by the Parliament of Ghana with the conclusion that the schools shall not be returned to the Churches. But is there, perhaps, any merit in the arguments of those who proposed that the schools should be returned in the first instance? What indeed were the arguments of the proponents and opponents of the turn of schools to the Churches that used to run them and the lesson to learn from both sides of the divide? It is against this backdrop that such an issue needs to be researched. The Agogo Presbyterian College of Education (APCE) would serve as a reference point. There is the need to know how the government has been running the schools compared to the Churches that used to run them towards an objective appraisal of the arguments and progress in maintenance of public educational institutions.

\section{Research Questions}

The study is set out to address how APCE has changed in terms of infrastructural development and academic performance of the students under the Missionaries administration and that of the Government of Ghana. The following sub questions were formulated to guide the study:

1. What is the state of infrastructural development under the Missionaries and Government in the College?

2. What is the state of management under the Missionaries and Government in the College?

3. What is the level of academic performance of the students under Missionaries and Government in the College?

\section{Geographic Scope}

The APCE is located in the Ashanti Region and lies between latitudes $6.30^{\circ}$ and $7.30^{\circ}$ North and longitudes $0.15^{\circ}$ and $1.20^{\circ}$ West. It shares boundaries with the Sekyere Kumawu District in the north, Kwahu East in the east, Asante Akim South District in the south and the Sekyere East District in the west. It covers a land area of 1,126 square kilometres constituting 4.6 percent of the region "es land area (24,389 square kilometres)

\section{Contextual scope}

Contextually, the study focused on the state of management and leadership and infrastructural development both under the regime of the Missionaries and the Government. It also sought to assess academic standard of the students, and the discipline of the College, qualification of the teachers, supervision, students ${ }^{\text {ee }}$ patronage of library and entry grade of students to the College with the view of establishing the progression or retrogression over the period. This assessment is intended to provide regionally relevant information while identifying opportunities to improve educational delivery in the colleges in Ghana.

\section{Methodology}


The researcher used qualitative research approach for the study. This is about exploring issues, understanding phenomena, and answering questions by analyzing and making sense of unstructured data. The research is a comparative and evaluative study. It is also exploratory in the sense that attempt was made to gather data on issues at stake. This approach requires a smaller scale for the study. Thus, large surveys do not need to be taken. Qualitative method is not based on figures but on understanding and evaluation. Data was gathered through library and field researches. The library research refers to consultation of literary work, while field research also constituted interviews and participant observation. The data was critically discussed. The qualitative research method was adopted for this study because the issues raised are not about numbers but quality of education and issues of maintenance of educational properties.

\section{Research Instruments}

The research instrument that was used to collect data are archival materials of the College and interview of some past Administrators or Principals of the College. The rest are some experienced members of the Local Church (Ebenezer Presbyterian Church, Agogo), some past students of the College and some tutors of the College including the current Principal of the College and students. Library materials were used to collect data. Data analysis was done through critical reflection and objective consideration of the findings.

\section{Population}

The object of study was Agogo Presbyterian College of Education. The target population for the study was one hundred and fifty (150) people and it constituted past Principals, the current principal, and members of the Local Presbyterian Church. Others were tutors of the College, past students and current students of the College. The rationale for the target population was to enable the researcher to get a fair representation of sample size to help in the study of the research. Also, the target population helped to provide the researcher with the needed information for the study.

\section{Sampling}

In this study, purposive sampling procedure was used to select the interviewees. This was because it involves a process whereby a sample is selected in a conscious and non-random manner for the purpose of achieving a specific goal. In other words, the researcher enlisted the subjects whom he considered to have the best knowledge and experience in the area of study. The sample size of the study was twenty (20) people constituting two (2) past Principals, the current Principal, and five (5) members of the local Church including the resident minister. The rest were two (2) tutors, five (5) past students and five (5) current students of the College. The reason for this sample size was to enable the researcher do effective study to come out with concrete outcome and result. This therefore enhanced the validity of the study.

\section{Justification for the Study}

The arguments for and against the return of the taken-over schools to the churches that used to own and run them is not knew and must have engaged scholarse attention at various times, since the take-over occurred in 1972. But the heated argument that engaged the nation over the return of the taken-over schools which was debated at the Parliament in January and February 2014 deserved a scholarly scrutiny and that was what this study sought to do. It compared how the church used to run Agogo Presbyterian College of Education and how the various governments have been running it since the take-over, vis-à-vis the argument for and against return of the takeover schools.

\section{Background of the Agogo Presbyterian College of Education}

The College was established in 1931 at the instance of the synod which was held in 1928 by the Presbyterian Church in the then Gold Coast when the Basel Mission was requested to establish a Girlse School in Ashanti. The request was in direct response to the Divine Commission to the Church universal to which the Presbyterian Church of Ghana belongs ,to go forth therefore and make all nations my disciples and teach them (Matthew 28:1920). In response to this Biblical injunction and in consonance with Dr. Aggrey ${ }^{\text {ee }}$ clarion call for the education of the girl child, the Basel Mission Girlse School and the Basel Mission Women ${ }^{\text {ee }}$ Training College were established at Agogo on the $1^{\text {st }}$ Day of March, 1931. These schools were founded by a young missionary teacher, Miss Helena Schalatter, who later became Mrs. Haegele Schlatter. She was later on in the year joined by two teachers, Rev, Buechner and Miss Goetz (Smith 1966:34). 
To ensure that high academic and moral standard were set and maintained, the students were subjected to the proverbial „Presbyterian Discipline ${ }^{e e}$. That level of discipline indeed yielded great and wonderful dividends for all the girls and women who passed through the four walls of both the Girls ${ }^{e e}$ Boarding School and the Women's Training College. Most of the women are now in very responsible positions and are very well known for their moral uprightness and general comportment and discipline. The Girls ${ }^{\text {ee }}$ School was used as a demonstration school by the students of the College. The year 1942 was a special landmark in the history of the College. In 1942, during World War Two, the West African Frontier Force took over the buildings of the Basel Mission Girlse School and the Training College. However, the pupils and the students were well received and comfortably settled at the Akropong Akuapem in the Eastern Region. The number of students who were sent to Akropong Akapem were two-hundred and ten (210). The people of Akropong greatly admired the humility, discipline and industry of the girls, and in 1943 the ,exiles ce came back to Agogo and they were the same number that went on exile (Archival source of the College).

In 1950, the Presbyterian Church of Ghana took over the College and the School from the Basel Mission which was administering the College and School by their missionaries. The College was renamed „Agogo Presbyterian Women ${ }^{\text {ee }}$ Training Collegee and the Mission Girlse School renamed „Agogo Presbyterian Girls ${ }^{\text {ee }}$ Middle Boarding Schoole under the Presbyterian Educational Unit (Smith 1966). In 1954, the chain of missionary leadership of the Girlse School came to an end when Miss Elizabeth Adjapong, a Ghanaian teacher, taking over the headship from Frieda Mischler. Before a Ghanaian took over the headship of the institutions, the infrastructural development of the College and the Girlse School was better as compared to what we see today. The numerical strength has rather increased at the moment as compared to missionary period. After Miss Elizabeth Adjapong came a long line of Ghanaian heads. Also in 1954, the Certificate „A $\mathrm{A}^{\text {ee }}$ course in accordance with Government decision, was transferred from Agogo to the Basel Mission at Aburi and the then Principal, Dr. Gertrud Juzi, two tutors and eighteen (18) student teachers left Agogo to start the course at Aburi.

Agogo concentrated on Certificate „B $\mathrm{B}^{\mathrm{ee}}$ course and a single stream Post „, $\mathrm{B}^{\mathrm{ee}}$ Course. A double stream 2-year Certificate „, $\mathrm{B}^{\mathrm{ec}}$ Course was run until 1963 when the 4-year Certificate „A $\mathrm{A}^{\text {ce }}$ was re-introduced (Debrunner 1967:37). During the 31 years of her existence, the College was headed by Basel Missionaries but in 1962, the first Ghanaian Principal of the College Miss Grace Boafo was appointed. She headed the College for three years and the last Basel Mission Principal; Miss Elizabeth Debrunner took over from her. In 1972, Miss Elizabeth Debrunner handed over the headship of the College to a Ghanaian, Miss Vida Annor Kwakye. In 1976, the result of the Common Entrance Examination for Girlse ${ }^{\text {ee }}$ School was so good that most of the girls in Middle Form Two (M.2) and Middle Form Three (M.3) were admitted into Secondary Schools. However, the Middle Form Four (M.4) was dropped (Debrunner 1967).

In 1976, after 45 years of its existence as a purely female institution, the College was turned into a coeducational institution with the enrolment of ten (10) male students and its name was accordingly changed from Agogo. Presbyterian Women's Training College to Agogo Presbyterian Training College. However, accommodation problems did not allow continued intake of male students into the College. In 1977, a Demonstration Kindergarten and Primary School were attached to the College. In 1987, in compliance with Government's policy of turning all Middle Schools into Junior Secondary Schools, which emphasized academic and vocational subjects, the Agogo Presbyterian Girls ${ }^{e e}$ Middle Boarding School gave way to the Agogo Junior Secondary School. Furthermore, September, 1979 saw the last of the female heads of the Girls ${ }^{e e}$ School, Miss Augusta Acquah, handing over the only class left in the school which is Middle Form three(M.3) to the first headmaster of the Agogo Junior Secondary, Mr. S. Akumah (Tarker 1979:37).

In 1980, the Agogo Presbyterian Girlse Middle Boarding School for which the Training College was established was completely phased out and the Agogo Junior Secondary was established in its place. Since its foundation, the Agogo Presbyterian Girlse Middle Boarding School and the Training College had produced teachers most of them now in prominent positions in many professions at home and abroad while others are happily settled in marriage and are contributing substantially to the progress of their family. In 1981 the College and the Agogo Presbyterian Hospital celebrated their Golden Jubilee in grand style. The then Head of State, prominent chiefs, top officials from Ministries of Education and Health and a lot of other dignitaries from Ghana and Overseas attended the celebration (Williamson 1992).

In this work, attention is focused on the comparison of infrastructural development during the missionary period and when government took over, the academic performance of the students during the two periods, the qualification of the tutors and the discipline of the students at the two dispensations. This helped the 
researcher to do analytical study in order to draw a suitable conclusion. The $60^{\text {th }}$ Anniversary was also celebrated in 1991 with great pageantry. In terms of infrastructural development, the College is far behind. The $15^{\text {th }}$ Principal of the College in the person of Rev. Mrs Esther Agbodeka took office in January, 2015. On $27^{\text {th }}$ January, 2015 at a Staff Meeting with the tutors she said it is on record that, Agogo College of Education and two other Colleges at the northern part of the country are most deprived in terms of infrastructure as all the Colleges are in the transition moving into tertiary status. This therefore gives indication that the state of infrastructure during the missionary period was far better than when government took over the management of the College. However, it is heart-warming to note that in 1996, the College came first out of the thirty-eight public Teacher Training Colleges in the country in the 3-year Post Secondary Final Part Two Examination. It could also be placed on record that the College was twice table tennis champion in 1997 and 1998 during the revived regional sports competition between Teacher Training Colleges in Ashanti and Brong Ahafo (The College Annual report in 1998).

Agogo Presbyterian College of Education (APCE) is dynamic, progressive and continually evolving for teacher preparation in the country. It offers comprehensive courses nationally and approved teacher-training curriculum which is both academic and professional. Since its inception, the College has run different preservice teacher training programmes at different times to meet teacher demands of this country. In September 2001, a new teacher education policy dubbed In-In-Out was introduced. This was followed by upgrading of Teacher Training Colleges into a Diploma Awarding Institutions in October, 2004. Central to this restructuring is the need to produce effective teachers for quality delivery in the basic schools in the country. The Diploma in Education Programme puts more emphasis on training a generalist teacher who is able to teach at both the Primary and Junior High School levels. In the programme, students spend the first two years on the College based activities and courses while the final year is spent outside the College and devoted to school attachment (internship) in the basic schools under the supervision of mentors and link tutors.

The courses taken consist of foundation and professional courses. The foundation courses are English Language Studies, Mathematics, Ghanaian Language and Culture, Music and Dance, Environmental and Social Studies, Religious and Moral Education, Pre-Vocational Skills (which constitute Art, Sewing and Catering). The rest of the foundation courses are Information and Communication Technology Education (ICT) and HIV/AIDS Education. The professional courses are Educational Studies which among other things comprise Educational Psychology, Philosophy of Education, Curriculum Studies, School Management, Guidance and Counselling, and Research Method. No account of the Presbyterian Church in Ghana would be complete without a survey of the part played by the Mission and the Church in the development of education in the country. According to Smith (1966:165) the educational system as it obtains today throughout Ghana was established by Basel Mission.

There was a six year period in Primary School followed by a four-year period in the Middle School. Up to the year 1882 the Colonial Government took little active interest in the schools established by the various Missions apart from making small annual grant of 100 pounds and later on 150 pounds to support them, in return for which the Missions reported the yearly attendance figures. In that year the Legislative Council enacted the „Ordinance for the Promotion and Assistance of Education in the Gold Coast Colony ${ }^{\text {ee }}$ which provided for the setting up of a Board of Education presided over by an inspector whose main task was to ensure that those bodies which conducted schools followed the condition attached to the grant-in-aid.

A more successful attempt to regulate the partnership of the Government and the Mission in education according to Smith(ibid) was made through the Education Ordinance of 1887 by which two types of schools were recognized, ,government ${ }^{\mathrm{ee}}$, (of which there were very few), and ,assisted ${ }^{\mathrm{ee}}$, which included all Mission Schools. The latter received grants only if they were open to all children regardless of religion or race, if they had an average of at least twenty pupils, were staffed by certificated teachers and if they included English Reading, Writing and Needlework (for girls) in the curriculum. In consonance of the above assertion, Agogo Presbyterian College of Education after its establishment was opened to all manner of

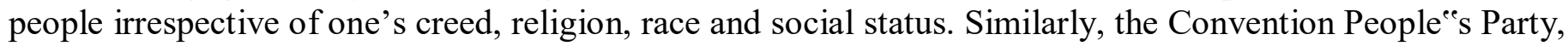
according to Aboagye (1999), was against the practice of compulsory religious instruction for pupils attending Church or Mission Schools.

The 1961 Education Act was put in place to ensure fairness among Ghanaian populace in their bid to send their awards to schools and colleges. In 1925, Sir Gordon Guggisberg, the Governor of Gold Coast (now Ghana), legislated sixteen principles of education which were aimed at promoting educational standard in 
the country. As his heart was in Africa and for that matter Ghana, he did all that he could to promote education in Ghana. Among other things, some of the sixteen principles of education he advocated for which are in line with Basel or Presbyterian system in offering education to pupils and students are as follows:

1. Primary education must be thorough and from the bottom to the top.

2. Equal opportunities should be given to both boys and girls in the area of education.

3. The staff of teachers must be of the highest possible quality.

4. Character training must take an important place in education.

5. Religious teaching should form part of school life.

6. Education must be free and compulsory.

7. There should be co-operation between the Government and Mission, and the latter should be subsidized for educational purposes.

8. The Government must have the ultimate control of education throughout the Gold Coast (ibid).

\section{Geographical location of the APCE}

Asante Akim North District is one of the newly created districts in Ghana in the year 2012. It was carved out of the then Asante Akim North Municipal and established by Legislative Instrument 2057 (Republic of Ghana, 2012). The District was inaugurated on $28_{\text {th }}$ June, 2012 with Agogo as its capital. Figure 2.1 shows the map of the Asante Akim North Municipal Assembly where the APCE is located.

Figure 1: APCE located in Agogo in the Asante Akim North Municipal Assembly

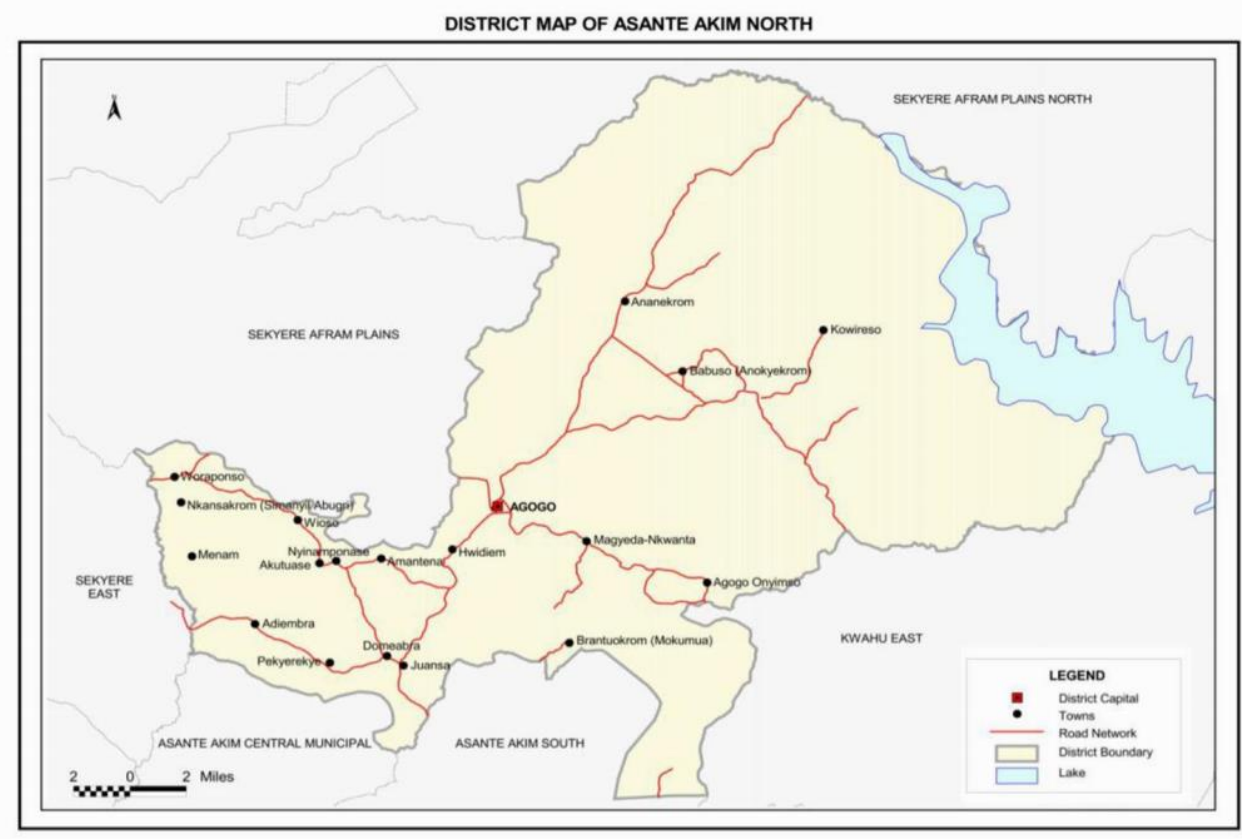

\section{Source: Ghana Statistical Service (2012)}

The District is located at the eastern part of the Ashanti Region and lies between latitudes $6^{\circ} 30^{\text {ee }}$ and $7^{\circ} 30^{\text {ee }}$ North and longitudes $0^{\circ} 15^{\circ e}$ and $1{ }^{\circ} 20^{\text {ee }}$ West. It shares boundaries with the Sekyere Kumawu District in the north, Kwahu East in the east, Asante Akim South District in the south and the Sekyere East District in the west. It covers a land area of 1,126 square kilometers constituting 4.6 percent of the region ${ }^{\text {ee }}$ land area (24,389 square kilometers). The total population of the District is 69,186 in 2010. The district has a more populous rural sector $(53.5 \%)$ than the urban sector $(46.5 \%)$.

\section{The Evacuation of the Agogo Basel Mission Girls' School and Training College to Akropong-} Akuapem during the Second World War (1942-45)

The Basel Mission Hospital situated on the same site as the Basel

Mission Girls ${ }^{\text {ee }}$ School had to close down when it became depleted of staff. For a while, it was used as a Health or Holiday Resort for officer in the Armed Forces. This incidence has been recorded in the Archival Source of Material of the College.

The students in the Girls School thought they were fortunate in escaping a fate similar to that of the Hospital. Though there were occasional rumours about the institution having to be closed down they were 
all proved to be unfounded until June 24, 1942. It was a Sunday and as the students were getting ready to go to Church, the Rev. K. H. Henking unexpectedly arrived from Kumasi. He was a frequent visitor to the School, but he visited at reasonable times. His arrival therefore at that time of the day aroused curiosity in those who saw him. He was the bearer of stunning news which he had come to deliver. The Basel Mission Girls ${ }^{e e}$ School had to close down as the buildings had been commandeered by the Army. The School had to evacuate or disband with a fortnight. In regard to this incidence, Smith (1966) wrote that in 1942, the Army commandeered the School, students and staff and moved en bloc to Akropong-Akuapem where they were housed in the College. Some students recounting the incident said that, ,they were late attending Church service in town that morning and the news like wild-fire had already spread to the town ${ }^{\text {ee }}$

The Girls ${ }^{e e}$ School was asked to sing. Tears rolled freely and uncontrollably down the faces of the women of the congregation. It was with some effort that they managed to sing to the end overwhelmed with grief and sorrow. The girls realized the implication of the edict, for though they would be given transfer certificate and be admitted in any school they chose to go, many of them especially those from some remote part of Ashanti knew with the closing down of the School went their hope of ever completing their schooling. Few ate lunch that day; everywhere sprawled on bed or sitting about with faces covered were girls weeping and mourning their cruel fate. Indeed, ,Rachel was weeping for children and would not be comforted (Matthew 2:18 KJV).

They started packing for the evacuation under the able leadership of the Miss Goetz and with tears and sorrow in their eyes; they did it with might, harmony and unity. Later Miss Kwabi came with her report that, „the Church and the Training College at Akropong would be pleased to welcome Agogo Girlse Mission Schools and the Training to Akropong with open armse. There was more weeping which could be associated with tears of relief. Then there was rejoicing, even dancing on the compound by the students. Eventually, the School packed up and was ready for general „Exoduse. Desks, tables and all the College and School equipment were sent to Akropong by road and rail.On the tenth day after the fateful news, the girls and the staff, with exception of Miss Guggenbuehl (who was left behind to see to the final tidying up of the compound and to travel down with the College livestock) boarded the truck at Konongo to Akropong. To some students, travelling on train was their first time experience and it was real adventure. It was with interest that they watch panorama of the country-side unfolded before them. The then District Commissioner made it a point to welcome them at the Koforidua Railway Station. The presence of the students and authorities from Agogo attracted attention and on-lookers commiserated when the news got to town. According to Kwamena-Poh (2011:33), the soil the Basel Missionaries came to till was spiritually well prepared. Interestingly the students and their missionary authorities found favour among the people they stayed with including the Church members in the town and the then Principal of the Akropong Presbyterian Training College, Mr. Dough Benzie, the Seminary building had been tidied up and pressure lamps lighted for them. Throughout their stay, the students indicated that, ,they found Mr. Benzies ${ }^{\text {ee }}$ sympathy, and understanding and a man of principle. (Smith 1966:95)

The studentse stay at Akropong was a landmark in the history of the School. It brought some sort of enlightenment to many. People were impressed by the fact that so many girls had chosen to leave their home in pursuit of education. Above all, they were impressed by the humility and industry of the girls and the students. Again, the people were struck by the cheerfulness, smart and clean appearance of the girls.

Furthermore, when the students put up two concerts that are variety show and a nativity play in the second and third term of 1943, the male students saw that the girls were in no way inferior to them. To conclude, prior to the evacuation, the students whose habit really in their old school wrote good English but had less opportunity in expressing themselves orally because they felt shy according to the casual on-lookers, rose up to the occasion under the challenges of the new environment. They were by no means paragons.

\section{The Structure (Organogram) of the College}

Agogo Presbyterian College of Education like any other human institution has structures. These help the institution to function effectively. Normally, the College works through the committee system and in that respect, it enables the entire staff members to actively get involved in the running of the College unlike a situation where the leadership of the College does everything. Figure 2.2 describes the structure of the College. At the apex of it are Ghana Education Service/ National Council of Tertiary Education (NCTE), the overall authorities of the College. They are followed by the Governing Council of the College which is composed of the Principal, Vice Principal, University of Cape Coast representative, Government appointee, 
Old Girls representative, the Presbyterian Church representative, representative of the Tutors of the College, the Senior Accountant and the representative of SRC.

Usually, the decisions the Council takes go a long way to affect the College positively. Thus, it is the highest decision body of the College and in extreme cases, it issues disciplinary measures against individuals or groups who may flout the rules of the College. The next in the hierarchy is the Principal who is the Chief Executive of the College. Although, there is an Accountant or Finance Officer, it is the Principal who controls the finances of the College. The Principal is assisted by Vice Principal who supports her in the dayto- day administration of the College. When the Principal is not around, the Vice Principal steps in to perform the duties on her behalf. Another organ to note in that order is the Librarian.

Library is an important unit in any academic environment and in that sense; it calls for someone who is acknowledgeable in librarianship to manage it. Therefore, in the era of transforming Colleges of Education into tertiary institution, a librarian is among the top hierarchy; he/she needs to have a second degree preferably in librarianship before he/she can work at a College of Education.

Figure 2.2 Organogram of the APCE

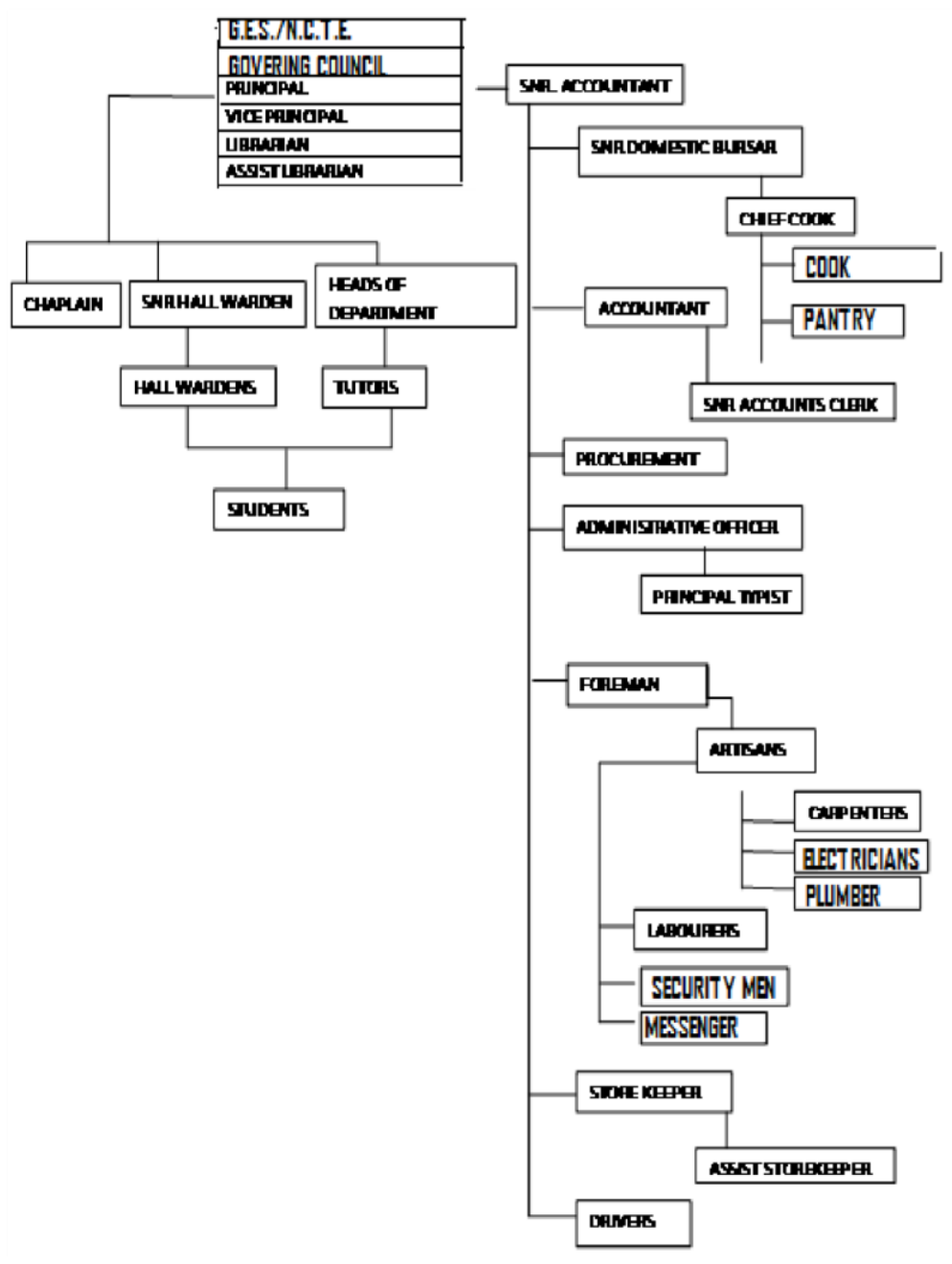

The Council meets as and when is necessary to take decisions about the wellbeing of the College. He/she makes sure that books are catalogued and arranged in their respective sections to ensure easy identification by students. He/she is assisted by Assistant Librarian so that the work over there could be done effectively and efficiently. The College Chaplain follows suit in that order and he/she is the representative of the Presbyterian Church. He reports to the Moderator of the Church through the General Manager of schools at the Presbyterian Headquarters at Osu, in Accra.

The Chaplain's reports of the College usually go a long way to affect the College either positively or negatively. Again, he/she sees to the spiritual fulfillment of the students at the College. In that wise, he 
organizes prayer meetings, revivals and retreats for the students. In addition to that, he/she sees to the proper management of various religious groups on campus so that their activities will not be counter-productive to their academic work on campus. One interesting issue worthy to commend is that, the Church allows every religious group of students to operate provided they will not be dangerous to the well-being of the students. And it is always the Chaplain who sees to the regulation of the activities of the religious group Hierarchically, the Senior Hall Warden (Senior House Mistress as it used to be known) is the next authority on the organogram. She coordinates the activities of the entire halls of the College. Hence, she does not work in isolation but rather work with the other hall wardens in the College. In all, the College has four halls and they are Helena Schlatter, Nana Ama Domitie, Grace Boafo and Elizabeth Debrunner. It is interesting to note that with the exception of Nana Ama Domitie the other three were Principals of the College. Thus, Helena Schlatter was the first Principal and Founder of the College. The seed she sewed at the College had yielded good dividend. Debrunner was also the $9^{\text {th }}$ Principal who was also honoured by naming one of the halls after her. Really, all the Principals did well but the College decided to name two of the halls after them. In the case of Grace Boafo, she was the first Ghanaian Principal after the work of the Missionaries so the authorities of the College thought it wise to honour her. Nana Ama Domitie on the other hand was a queen mother of Agogo Traditional Area and according to Nana Akuoko Sarpong, the Omanhene of the Agogo Traditional Area, the Queen was someone who was interested in education despite the fact that she was an illiterate. Therefore when she was consulted in naming one of the halls after one of the late queens, he gave Nana Ama Domitiees name. In an interview with a former Principal of the College, Mrs. Grace Ofosuhemaa Odjidja, she said "Nana Akuoko Sarpong indicated that Nana Ama Domitie even contributed substantially towards his education else he would not have gone to school to become what he is".

The Heads of Departments are the next in terms of hierarchy on the structure. They see to the right management of their respective departments and report accordingly to the Principal through the Vice Principal of the College. The office of the Head of Department is held for a given duration normally two years after which the next person comes in depending on the criteria of each department. This situation enables everybody at least to have the feel of that office. In all, the departments are five in number and they are Science and Physical Education, Mathematics and ICT, Language and Culture, Education Studies, and Social Sciences. The Head of Departments see to it that regular meetings of each department are held and also action plan of each tutor for a given semester is prepared and submitted to him/her accordingly. Also the heads make sure that their members submit their continuous assessment accordingly to the Assessment Officer for onward submission to the Institute of Education, University of Cape Coast.

The Hall Wardens are the next authority on the organogram. They control activities of the various halls and report to the Senior Hall Warden. They see to the welfare of their respective members of the hall. For instance, they see to the issuance of exeats to their students when they want to go out of the College and report back to them when the students return. After the Hall Warden are the tutors who are on the same level with them. They see to the academic activities of the College by teaching the students the various courses or subjects like Mathematics, English, Integrated Science, Religious and Moral Education just to mention a few.

Besides, they also help in the extra-curricular activities like sports in the College. Below the tutors are the students whom the tutors teach and they are the main focus as far as the existence of the College is concern. It is important to note that the achievement of an institution is assessed in terms of its students ${ }^{\text {ee }}$ success in external examinations. In view of this the students of the College co-operate with their tutors in order to achieve academic excellence. On the other side of structure also begins the Senior Accountant who heads the non-teaching staff of the College; and examples of some of the people who work under him are Senior Domestic Bursar, Chief Cook, Cooks, Senior Accounts Clerk, Procurement Officer, Administrative Officer, Principal Typist just to mention a few. Their hierarchy follows in that order as indicated on the diagram till the drivers who are at the bottom of the structure.

\section{The Mission, Vision and Objectives of APCE}

Like any corporate institution or organization, Agogo Presbyterian College of Education has its own mission, vision and objectives. These serve as road map to guide the College in executing her duties of providing services to humanity in the form of training female teachers to teach our Basic schools in the country. They are as follow: 


\section{Mission}

The College shall train efficient and effective female teachers to teach in Basic schools in Ghana.

\section{Vision}

The College shall become one of the female Colleges in Ghana which shall produce female teachers of good moral, academic and professional excellence who will be good role models to their pupils and other members of their gender in the communities they serve (Annual Report of the College

2010: 5).

\section{Themes and Objectives}

The objectives of the Agogo Presbyterian College of Education's Strategic Plan (2004-2014) were grouped under four themes as follows:

- Improving Academic Excellence

1 To attract, recruit and retain highly qualified professional staff in all departments

2 To improve professional and academic competencies of staff

- Improving Infrastructure

1. To improve upon the physical facilities of the College.

2. To improve services and other facilities in the College.

3. To improve information and communication system in the College.

- Initiating Innovative Programmes

1 To support national effort in the fight against HIV/AIDS on the College campus and areas of internship

2 To design programmes to help improve performance of pupils at the Practice School and other Basic Schools in the locality

3 Ensuring Financial Self-Sufficiency

4 To raise funds to support the College's programme

The above mission, vision and objectives are in the right direction which to some extent serves as parameters to guide the College to realize its dreams and goals. Without them, the College may go wayward hence, it is paramount that like any other institution they were in place to serve as guiding principles. From the record indicated above by the former Principal, Mrs. Grace Odjidja, also indicated some strengths and weaknesses of the College and they are as follows.

\section{Strengths}

1 The College is strategically placed to serve three (3) districts namely Asante Akyem North, Asante Akyem South, and Ejisu Juaben at the time of Mrs Grace Odjidja.(It should however be noted that it was until June, 2012 that Asante Akyem Central was created to add up to the number of districts the College serves to become four (4) ). To this end, the Colleges sends most of her third year students to the above districts to do their teaching practice.

2 The College is close to a major hospital (Agogo Presbyterian

Hospital). It renders health delivery services to the students when the College is in session. Also during every academic year, the hospital offers medical examination to the first year students who are admitted into the College

3 The College is situated in the farming area where foodstuffs are in constant supply. In view of this the College gets enough food supplies to feed its students all year round at moderate prices.

4 The College is also close to the Ghana Commercial Bank in Agogo. The Bank therefore renders financial services to both the students, the administration of the College, the staff and the entire community

5 Agogo Presbyterian College of Education has competent and efficient teaching staff as well as qualified and skillful supporting staff.

6 There is also land for development projects but it is not well utilized to achieve the maximum benefits.

\section{Weaknesses}

1. There is inadequate accommodation for both teaching and nonteaching staff. This situation however deprives the College in getting more qualified teachers to teach. 
2. The security at the campus is also poor and porous. In view of that there are constant theft cases at the College which affects both teachers and students. It is surprising to learn that the thieves sometimes break into the students ${ }^{\text {ee }}$ halls while they are asleep and steal their belongings.

3. The College has the problem of inadequate facilities like computers, library facilities and science equipment. This situation affects the College as far as teaching and learning is concern especially in the area of the study of Science

\section{Threat}

1. Encroachment on land: People from the community are constantly harassing the authorities of the College by encroaching on their land.

They are putting up building on the land and that is affecting the College facilities.

2. Incomplete fencing: There are many outlets that lead to the College; these expose the College to insecurity.

3. Due to the problem of inadequate accommodation and lack of incentive packages to retain qualified staff, they normally do not stay there for long; they leave for other places for better opportunities

4. Inadequate funding: The College relies on the central government alone for funding which is inadequate and sometimes not reliable. It therefore affects the College for any possible development it wants to undertake.

\section{Level of academic standards}

The survey noticed that on average the academic performance of the students were good. However, most students do not perform so well in the following subjects Integrated Science, Mathematics and English Language. This was mainly due to the poor foundation of the students from the secondary education.

\section{Entry grades of students}

The study found that while enrolment rates at the APCE have increased, learning achievements were found to be below the expected standards. Some students admitted have weak grades either in Mathematics or English Language or Science. Therefore the trainee teachers struggle to understand the content of the subject matter and affect their delivery. This was due to the inadequate inspections hence teachers and school management are not held accountable for the declining educational achievement in the college.

\section{Instructional materials}

The study observed that Colleges and Schools depended on the Curriculum Research and Development Division (C.R.D.D.) for their study materials. This Division with the GES are charged with the responsibility of developing and producing the curriculum materials for academic work in our Schools and Colleges. Examples of these materials are textbooks, syllabuses, teacher's manual or guide for various subjects, etc. However, there was generally inadequacy in the provision of instructional materials which leads to focusing more on theoretical teaching leading to trainees lacking proficiency in their chosen fields of specialization.

\section{Teachers' qualification}

Agogo Presbyterian College of Education has a teaching staff of thirty (30) tutors including the Principal of the College. Out of the total number of the tutors, twenty- seven (27) have their second degrees whilst three (3) are not having it. This has enhanced the academic and professional qualifications of the teacher and it indicates the teacheres quality.

\section{Level of discipline in APCE}

The level of discipline especially among students were observed to have remained relatively stable both under the Missionaries and the since the government took-over. The authorities of Agogo Presbyterian College of Education have not relented in their effort to punish students who go contrary to the College rules and regulations. Offenders were made to go on either internal or external suspension in respect of what the student has done or committed.

\section{Patronage of library}


The study also showed that despite the inadequate capacity of the library to accommodate the students, it has been the main source of further information besides the classroom work for assignment, project work or group work. However, the obsoleteness of the books in the library discourage the use of the facility by both teacher and students. It was also observed that the librarians lacked the requisite skills to man the library efficiently. This finding affirms Amoako (1996) assertion that library may be provided but the students may not patronize it due to inadequate space and insufficient and outmoded books.

\section{Parliamentary debate on the take-over schools}

The study observed varying positions for Missions Schools to be handed over to Churches by the Government. These advocates maintained that there is lack of proper supervision, falling standard of education, moral decadence and financial constraints have been cited as the bases for the return of the Mission Schools to their original owners. It therefore perceived that government has not managed these schools effectively coupled with infrastructural deficit over the years. There is so much waywardness now and as a nation, we need to rise up to our responsibilities before we are overtaken by event." This has resulted into low healthy competition between schools, and that moral decadence is on the rise and discipline has been sacrificed.

Waywardness, indiscipline, lawlessness and crime of all kinds, is becoming common since the state tookover of schools from the various religions. The churches had been relegated to the background in the country ${ }^{\text {ee }}$ educational system. For instance, those in support of the argument believe that the current system gives education in Ghana collective ownership and in this regard the Church has a role play.

On the contrary, Archbishop Palmer Buckel of Catholic Church in

Accra and Dr. (Mrs) Margaret Nkrumah, former Principal of SOS Hermann Gneimer International College, Tema, who also opposed the transfer of the mission schools to the churches, posed the following questions:

1. How many Ghanaian children have the opportunity to go to school and how is the character of those who do not go to school formed?

2. And what kind of arrangement will be there? Will it be such a complete take-over that the Missions will fund their schools, pay salaries and look for their own teachers and non-teaching staff?

3. Will they admit students of other religious beliefs and force them to renounce their religion and become members of a different faith, such as Christians becoming Muslims and Muslims becoming Christians?

4. Will the Missions pay back to the State all the money sunk into those schools by way of infrastructure, equipment and materials?

5. What is the proof that private schools are doing better than public schools in Ghana?

6. Will all these problems be solved as soon as the Missions take back their schools?

7. Will they admit students of other religious beliefs and force them to renounce their religion and become members of a different faith, such as Christians becoming Muslims and Muslims becoming Christians?

8. Will the Missions pay back to the State all the money sunk into those schools by way of infrastructure, equipment and materials

They however suggested the need to adequately engage all the stakeholders in developing education delivery in Ghana. Stakeholders should rather channel their efforts to addressing the over-crowded classrooms, quantitatively and qualitatively inadequate supply of teaching staff, deplorable school buildings, and lack of teaching and learning materials, poor supervision and very poor funding etc. that has led to the falling standards of education in the country.

\section{Conclusions of the study}

Education is a necessary element in the development of every nation.

It is an important tool for the optimum development of a nation's human or man power resources, which contributes largely to a nation's total economic growth. However, APCE is facing a challenging period in its development. The recommendations proposed in this study are to provide informative basis for the Government and all other stakeholders the collaborative efforts needed to affect College of Education in Ghana. This will require innovation and inventiveness in the mobilization of all resources both human and 
financial as well as participation of all stakeholders in order to realize the objectives of our education reform programme.

Improvements in access and quality of education at all the Colleges of Education will provide the needed impetus to the reform programme as well as to the development agenda of creating wealth and reducing poverty in Ghana. The proposed reforms will contribute to an increased funding gap for the entire education sector. There will be the need therefore as already indicated to attract increased levels of external funding, including increasing levels of support from the private sector, ad opt cost-recovery strategies and also look to improve efficiencies in education delivery in order to meet the increasing resource needed. Co-operation and dialogue between government, the private sector, development partners and all stakeholders will drive forward the reform process and ensure that the education sector achieves the derived impact on the growth of the national economy.

\section{Recommendations}

These recommendations seek to provide overall measures to improve policy action on college educational delivery to foster development in the Ghana:

1. The relationship between the Ministry of Education and its agencies, the Regions, the Districts and the schools, i.e. between the policymakers and the delivery system, is of major importance in the context of the education system. The relationship needs to be built on mutual trust, with the Ministry providing relevant policies, guidance and support to the agencies and to schools and teachers, with schools taking greater responsibility for their own improvement and school staff working with local communities towards a common goal. For this to develop, both the management structure and the management culture need to focus on service and support rather than on command and control. This implies changes within the Ministry at one extreme and within individual schools at the other.

2. The Ministry of Education should therefore make all the necessary effort to increase investment in the promotion of Mathematics, Science and Technology, particularly in junior secondary schools. In addition, throughout the system, from Primary Schools to the institutions of higher learning, there will be greater attention paid to encouraging all actors in promoting applications of Information and Communication Technology (ICT) to daily activities, whether at a personal level or in the workplace. Again there should also be improvements in the learning environment. This will need to be complemented by the strengthening of the teaching staff. Teachers require targeted pedagogical training. Efforts should also be made to motivate teachers to stay in the profession, the average teaching life of a teacher being only 4 or 5 year is a considerable waste of public investment.

Human resource policy should be developed by the Ministry of Education in collaboration with the other stakeholders to adequately address staff matters related to terms and conditions of service including recruitment, capacity building, promotion, deployment and redeployment at all levels. This is expected to enhance or boost the morale and motivation of staff. Efforts should be put in place to strengthen the infrastructure with clear guideline on their staff development. More so, teaching and teacher education should be professionalized and call for government to grant training colleges full academic and professional responsibility.

3. The study also recommends the need of teaching basic research skills among the student teachers and teachers at the lower levels to encourage critical, independent and investigative thinking among the young learners. Again, adequate and well trained staff in ICT be put in place and for the curriculum to be regularly reviewed to meet skills demanded that are constantly changing.

4. Semi-autonomous Education Standards and Quality Assurance Commission should be established to be the custodian of standards and quality in education and it will hold to account all service providers across the education sector.

\section{Suggestions for Further Research}

The scope of the study was limited to Agogo Presbyterian College of Education. However, further research work on the study can be done in other Presbyterian Colleges of Education in the country (Ghana).

Again, a future researcher could also consider the situation which is happening in the Catholic based Colleges of Education. Other factors which the researcher did not investigate but could be of importance like feeding should be taken into consideration by a future researcher who would decide to carry out similar research work. 
Acknowledgements: Mrs. Gloria Mensah Bonsu, Mrs. Rose Adjei, Dominic Adom-Adjei, Herbert AdomAdjei, Bridgit Adom-Adjei, Friedel Okoampah Mensah Bonsu, Frederick Asante Mensah Bonsu Jnr. and Fidelyne Gyamfuaa Mensah Bonsu

\section{References}

[1] Aboagye, J. K. (1999). Handing over schools to the Missions: A historical review of arguments. Winneba: The Winneba Education Bulletin (WEB).

[2] Aboagye, S. (2014). Teachers and the disciplinary committees of schools to work hard to address indiscipline among students. The Daily Graphic, 5. Retrieved on http://www.graphic.com.gh/news/education/let-saddress-indiscipline-among- $\quad$ students.html

[3] Aduonum, K. M. (2003). Democracy in educational reforms - What are the goals? Ghanaian Times, 140(48), 1.

[4] Aduonum, K. M. (2003). Democracy In Educational Reforms - What are the goals?

[5] Ghanaian Times 48(14), 1.

[6] Agyeman, D. K. (1993). Sociology of education for African student. Accra: Black Mark Ltd.

[7] Allemna, A. (1992). User Education in University Libraries in Ghana. Education Library Journal, 233(1), 40-47.

[8] Amoako, L. A. (1996). The plight of developing schools in Ghana: The educator. Accra: Eddy Williams Ltd.

[9] Andrew, C. (1994). Education, society and development in Ghana. Accra: Unimax Publisher Ltd.

[10] Annual Report of the College (2010). Agogo Presbyterian College of Education. Ghana.

[11] Annual Report of the College, (2003). Agogo Presbyterian College of Education. Ghana.

[12] Antwi, M. K. (1992). Education, society and development in Ghana. Accra: Unimax Publisher Ltd.

[13] Archival Source of the College. Agogo Presbyterian College of Education. Ghana.

[14] Arends, R. I. (1991). Learning to teach. New York: McGraw-Hill Inc.

[15] Ary, D., Jacobs, L. C., \& Razavieh, A. (1985). Introduction to research in Education. Boston: Holt, Rinehart and Winston Inc.

[16] Ashton, P., \& Crocker, L. (1985). Introduction to research in Education. Boston: Holt, Rinehart and Winston Inc.

[17] Ashton, P., \& Crocker, L. (1987). Systematic study of planned variation. The Essential Focus of Teacher Education Reform. Journal of Teacher Education, 38, 2 - 8.

[18] Asiedu-Akrofi, K. (1978). School organization in modern Africa. Accra: Ghana Publishing Corp.

[19] Bame, K. N. (1991). Teacher motivation and retention in Ghana. Accra: Ghana University Press.

[20] Barcan, A. (1995). The struggle over teacher training. Agenda, 2(2), 49-62.

[21] Berrien, F. K. (1968). General and social system. Piscataway: Rutgers University Press.

[22] Bertalanffy, L. V. (1988). General system theory: Foundations, development, applications. New York: George Braziller.

[23] Blake, J. (1981). Family size and quality of children. Demography, 18, 14-22.

[24] Calhoun, C., Light, D., \& Keller, S. (1994). Sociology (6th ed.). London: McGraw-Hill Inc.

[25] Cascio, W. F. (1992). Managing human resources, productivity, quality of work life, profits. New York: McGraw-Hills.

[26] Corwin, R. G. (1981). Professional persons in organizations. Educational

[27] Administration Quarterly, 1, 16 - 20.

[28] Crowther, J. (1995). Oxford English dictionary. Oxford: Oxford University Press.

[29] Cypher, T., \& Willover, D. J. (1994). The work behaviour of secondary school teachers. Journal of Research and Development, 18, $17-24$.

[30] Darling-Hammond, D. (2000). Teacher quality and student achievement. EPPA, 8, $1-10$.

[31] Davis, K., \& Newstron, J. W. (1985). Human behaviour at work, organizational behavior. New York: McGraw - Hill.

[32] Debrunner, H. W. (1967). A history of Christianity in question. Accra: Waterville Publishing House.

[33] Durkheim, E. (1936). The elementary forms of the religious life. London: 
[34] George Allen \& Unwin Ltd.

[35] Farrant, J. S. (1984). Principles and practice of education. Essex: Longman.

[36] Gipps, C. (1994). Beyond testing: Towards a theory of educational assessment. Boston: The Falmer Press.

[37] Gladys, F. (2016). Three armed students of St. Augustine College robbing a taxi driver of his car. Ghanaian Times 213(41), 6.

[38] Guthrie, J. W. (Ed.). (1975). Encyclopaedia of education. London: Macmillan.

[39] Gyasi, E. K. (2014). Nobody seems to be concerned about the moral

[40] upbringing of children to instill discipline and the respect for authority in them. The Chronicle, $1(29), 14$.

[41] Gyasi, E. K. (2014). Still on falling standard of education. Port Harcourt: Rivers State Broadcasting Corporation.

[42] Haddad, W. W. D., Carnoy, M., Rinaldi, R., \& Regel, O. (1990). Education and development: Evidence for new priorities. Washington DC: World Bank Discussion Papers.

[43] Hsiao, H. C. (2007). A performance-based Evaluation model for Engineering

[44] Education Programmes. Global Journal of Engineering Education, 11(1), 1 - 10.

[45] James, K. (2011). Nigeria: Delta Returns 40 Schools to Former Missionary Owners. The Daily Graphic, 21, 14.

[46] Julien, M. M. A., \& DE Paris, (1817). Plan and preliminary for work on comparative education. Delaunay, Paris: Saint-Sulpice.

[47] Keating, J. (2001). The efficacy of CPD: Its impact upon classroom practice. Professional Development Today, 4, 2 - 19.

[48] Kraft, R. J. (1994). Teaching and learning in Ghana. Accra, Ghana: Mitchel Group.

[49] Kudadjie, J. N. (1995). Moral renewal in Ghana ideals, realities and possibilities. Accra: Asempa Publishers.

[50] Kusi, H. (2012). Doing qualitative research: A guide for researcher. Accra: Empong Press.

[51] Kwame A. B. (2001). Two students grabbed with ammunition. Ghanaian

[52] Times, 20(8), 13.

[53] Kwamena-Poh, M. A. (2011). Vision and achievement: A hundred and fifty years of the Presbyterian Church of Ghana (1828 - 1978). Accra: Waterville Publishing House.

[54] Lockheed, M. (1991). Improving education. Education Review, 16(3), 51-60.

[55] Madeus, G. F., \& Stufflebeam, D. L. (1989). Educational evaluation: The works of Ralph Tyler. Boston, MA: Kluwer Academic Press.

[56] Mankoe, J. O. (2002). Educational administration and management in Ghana. Accra: Ghana Publishing Company.

[57] Margaret, E. N. (2007). Job of parent to bring up their children to teach them their cultural, moral and religious values. Daily Guide, 10(12), 19.

[58] Marian, E. A. (2014). Government to hand over all mission schools to churches. General Telegraph, $8(2), 19$.

[59] Mckeachie, W. J. (1986). Teaching tips: A guide book for the beginning college teacher. Lexington, MA: DC Health and Company.

[60] McWilliams, H. O., \& Kwamena-Poh, M. A. (1975). Development of education in Ghana. London: Longman Group Co.

[61] Nacino-Brown, R., Oke, F. E., \& Brown, D. P. (1990). Curriculum and instruction: An introduction to methods of teaching. Hon Kong: Macmillan.

[62] Neagley, R. I., \& Evans, N. D. (1970). Handbook for effective supervision of instruction. Englewood Cliff, NY: Prentice-Hall Inc.

[63] Nortsu-Kotoe, P. (2014). Missions to run their schools? Daily Guide, 12(10), 19.

[64] Ohuche, R. O., \& Akeju, S. A. (1998). Measurement and evaluation in education. Onitsha: African FEP Publishers Ltd.

[65] Okumbe, J. A. (1998). Educational management, theory and practice. Nairobi: Nairobi University Press.

[66] Owolabi, J. (1983). Introduction to school management. Ibadan: Ibadan University Press. 
[67] Palmer-Buckle, C. (2005). Sounded a note of caution and also gave very useful advice to his clerical brethren. Ghanaian Time, 10(6), 8.

[68] Peterson, R. W. K. (1979). Values, education and the adult. International

[69] Library of the Philosophy of Education, 16(1), 17-25.

[70] Proctor, P. (Ed.) (1996). Cambridge international dictionary of English.

[71] Cambridge: Cambridge University Press.

[72] Queen, D. A. (Ed) (2002). The Kanga L/A Primary School success story. Accra: US Embassy Public Affairs Section Periodical.

[73] Rebore, R. W. (1982). Personnel administration in education. Englewood

[74] Cliff, NY: Prentice-Hall Inc.

[75] Schon, D. (1983). The reflective practitioner. London: Temple Smith.

[76] Sekyere, E. A. (2002). Teachers guide to promotion interviews. Kumasi: Afosek Education Consultancy Centre.

[77] Seth, B. (2013). Let's debate return of schools to churches. The Daily Graphic, 15, 19.

[78] Seth, B. (2014). Fury over mission school fees: Church-run schools in Nigeria made a shift in cost. Fury Over Fees, 56(6), 10.

[79] Smith, N. (1966). The Presbyterian Church of Ghana, 1835-1960: A younger church in a changing society. Accra: Ghana University Press.

[80] Stoner, J. A. E., Freeman, R. E. S., \& Gilbert, D. R. (1995). Management (6th ed.). Englewood Cliffs, NY: Prentice-Hall Inc.

[81] Sugarman, B. (1973). The school and moral development: London: Croom Helm Ltd.

[82] Tamakloe, E. K., Amedahe, F. K., \& Atta, E. T. (1996). Principles and methods of teaching. Accra: Black Mask Ltd.

[83] Tanner, D., \& Tanner, L. M. (1980). Curriculum development (2nd ed.). London: Macmillan Publishing Co.

[84] Tarker, J. (1979). The origins of bibliographic instruction in academic libraries. New York: K. G. \& Sons.

[85] Thomas, F. Jnr. (2014). Ghanaian parliament supports mission take over of schools. Daily Graphic, $511(21), 7$.

[86] Weber, C. W. (1993). International influences and Baptist mission in West Cameroon: GermanAmerican missionary endeavour under international mandate and British Colonialism. Leiden: Brill Academic Publishers.

[87] Williamson, K. M. (1992). Relevance or rigor: A case for teacher as researcher. Journal of Physical Education, Recreation and Dance, 63(9), 19-21. 